\title{
PARTAI POLITIK DAN SISTIM DEMOKRASI DI INDONESIA
}

\author{
Aiyub Mohsin \\ Dosen FISIP Universitas Nasional dan UIN Jakarta \\ aiyub_mohsin@yahoo.com
}

\begin{abstract}
ABSTRAK
Masyarakat Indonesia telah mengenal Partai-partai Politik (Parpol) sejak masa penjajahan, dan berlanjut terus setelah Indonesia memproklamirkan kemerdekaannya pada tanggal 17 Agustus 1945. Perkembangan parpol itu erat kaitannya dengan sistim politik yang terbentuk, yang dalam kasus Indonesia sistim politik itu tetap berlabel demokrasi dengan nama yang bermacam-macam. Pada masa Demokrasi Liberal (1945-1959) muncul begitu banyak parpol dan organisasi kemasyarakatan (ormas). Pada Pemilu 1955 yang pertama kali diadakan setelah Indonesia merdeka, sebanyak 39 parpol ikut serta, ditambah ormas, perorangan dan kelompok pemilih kesemuanya berjumlah 100 sebagai kontestan pemilu. Pada masa Demokrasi Terpimpin (1959-1966) hanya 10 parpol yang di izinkan pemerintah pada waktu itu yang disebut "Orde Lama", dan tidak ada pemilu kerena oleh rezim yang berkuasa dianggap "negara belum cukup stabil untuk mengadakan pemilu". Pemilu pertama pada masa Demokrasi Pancasila (1966-1998) berlangsung pada tahun 1971 diikuti oleh 10 parpol dan 1 (satu) ormas bentukan penguasa yang disebut "Orde Baru". Ormas itu bernama Golongan Karya atau Golkar yang tidak mau disebut parpol tapi ikut serta sebagai kontestan pemilu. Pada Pemilu 1977 dan pemilu-pemilu berikutnya sampai Orde Baru digantikan oleh "Orde Reformasi" kontestan pemilu hanya terdiri dari 2 (dua) parpol dan Golkar. Pada pemilu Era Reformasi (1998-sampai kini) jumlah parpol sebagai peserta pemilu berfluktuasi. Pelaksanaan demokrasi pada era reformasi ini sangat kental bernuansa Demokrasi Liberal dengan kebebasan yang sangat luas dan dalam.
\end{abstract}

Kata kunci : Demokrasi, Partai Politik dan Pemilu.

\begin{abstract}
The Republic of Indonesia since 1945 when it proclaimed its independent from the Dutch colonialism adopted democracy as political system. In its political development, democracy in Indonesia had many names or label. From 1945 until 1959, the Republic of Indonesia adopted and implemented which is commonly known as Liberal Democracy. During the period of 1945 - 1959, the government of Indonesia held successfully general election with 39 political parties as well as mass organization and group of constituens which all together 100 participants in the general election. From 1959 until 1966, democracy which was took on called Guided Democracy.During this period there was no general election eventhough some political parties were permitted to exist by the current rezime. The rezime was of the opinion that the Indonesian people was not ready yet for carrying out generah election. After aborted Communist coup d'etat at 30 September 1965, new government arised, and they
\end{abstract}


called their government as New Order or Orba in Bahasa Indonesia. The new order remained to adopt democracy in political system which was labelled as Democracy Pancasila, referred to the nation and state philosophy. The new order government organized six times general election which was held in 1971 1977, 1982, 1987, 1992 and 1997. In general election 1973 there was 10 political parties and 1 mass organization called Golkar, formed by government as main political power of Orba. Since 1977 the election participants were only two parties, the United Party for Development (PPP), the Indonesian Democratic Party (PDI) and Golkar. Then Golkar developed as hegemonic party, ardent and strong supporter to the Orba government, and always winning in every general election. When Reformation Era came in 1998, the reformation government named its democracy as Demokrasi Reformasi, and as of 1998 until now, had successfully organized 4(four) times general elections with its participants fluctuated. In 1999's general election the participants was 48 political parties, 2004' election was 24 parties, 2009's election was 38 parties, 2014 ' general election was 12 parties. For 2019's general election, 16 parties was declared by the General Election Commission or KPU as participants nationally. From theoretical perspectives on democracy, whatever labelled or named, democracy implemented in Indonesia formally as Democracy.

Key words : Democracy, Political Parties, General Election.

\section{Perkembangan Kepartaian}

Timbul tenggelamnya partai-partai politik di Indonesia erat kaitannya dengan sistim politik yang terbentuk dan mendukung atau menghambat perkembangan dari partai-partai itu. Secara historis dan sosiologis, jauh sebelum kemerdekaan Indonesia diproklamirkan pada tanggal 17 Agustus 1945, partai-partai politik telah memerankan fungsinya sebagai penyalur aspirasi masyarakat yang bercorak aliran seperti Syarikat Islam (SI) yang terbentuk pada tahun 1912, perkembangan dari Syarikat Dagang Islam yang didirikan pada tahun 1905 oleh Haji Samanhudi, seorang pedagang batik di Solo. Pada tahun 1921 S.I menjadi Partai Syarikat Islam (PSI). Begitupun Budi Oetomo yang dibentuk oleh para mahasiswa kedokteran pada tahun 1908, kemudian menjadi partai politik pada tahun 1917. 10 tahun kemudian berdiri Partai Nasional Indonesia (PNI), pada tahun 1927, oleh Soekarno dan Sartono, tokoh-tokoh pergerakan nasional. Kesemua partai politik itu mempunyai tujuan yang sama yaitu mencapai kemerdekaan Indonesia

Setelah kemerdekaan Indonesia diproklamirkan, kehadiran partai-partai politik mendapatkan legalitas melalui Maklumat Pemerintah yang ditandatangani Wakil Presiden Moh. Hatta, tanggal 3 November 1945. Dalam Maklumat itu tertera antara lain: Pemerintah menyukai timbulnya partai-partai politik kerena dengan partai-partai politik itulah dapat dipimpin ke jalan yang teratur segala aliran yang ada dalam masyarakat. Maklumat Pemerintah itu disambut hangat oleh rakyat dengan membentuk berbagai macam partai, dalam kurun waktu 5 tahun (1945-1950) tercatat 27 partai (Pamungkas, 2012:151) dengan ideologi atau aliran baik secara jelas maupun tidak jelas dari perspektif ideologi kepartaian. Adapun sistim politik yang terwujud adalah sistim politik Demokrasi Liberal, yang memberi kebebasan kepada masyarakat untuk membentuk partai-partai politik, dan mengizinkan selain partai politik, kelompok masyarakat yang tergabung dalam organisasi, perorangan, 
dan malahan hanya sebagai kelompok pemilih ikut serta pada Pemilu 1955 sebagai kontestan, sehingga pada Pemilihan Umum (Pemilu) pertama tahun 1955 untuk memilih anggota parlemen atau Dewan Perwakilan Rakyat terdapat 100 kontestan, yang terbagi dalam kelompok partai politik 39, kelompok organisasi 46, kelompok perorangan 9 dan kelompok Pemilih 6. Sedangkan untuk memilih anggota Konstituante yang akan merumuskan Konstitusi permanen bagi Indonesia, tercatat sebanyak 91 partai dan kelompok perorangan (Pamungkas, 2012: 170-171). Pemilu 1955 untuk memilih anggota DPR yang berlangsung pada tanggal 29 September 1955, dan untuk memilih anggota Konstituante tanggal 15 Desember 1955 menghasilkan 5 (lima) besar partai yakni (1) PNI beraliran Nasionalis, (2) Majlis Syura Muslimin Indonesia ( Masyumi ) beraliran Islam "modernis", (3) Nahdlatul Ulama (NU) beraliran Islam "tradisionalis", (4) PKI beraliran komunis marxis, (5) PSII beraliran Islam "normatif". Prestasi kelima besar itu dalam pemilihan anggota DPR adalah sebagai berikut: PNI berhasil mendapatkan suara sebanyak 8.434.653 $(22,32 \%)$ dari jumlah pemilih dengan jumlah kursi DPR sebanyak 57, Masyumi, 7.903 .886 (20,92\%) dengan jumlah kursi 57, Nahdlatul Ulama, mendapatkan 6.955 .141 suara $(18,41 \%$,) dengan jumlah kursi 45 , PKI, mendapatkan suara 6.179.914 (16,36\%) dengan jumlah kursi 39, PSII, mendapatkan suara 1.091.160 $(2,89 \%)$ hanya berhasil mendapatkan 8 kursi DPR. PSII merupakan kelanjutan dari PSI yang berdiri pada tahun 1921. Jumlah pemilih yang terdaftar untuk Pemilu 1955 sebanyak 43.104.464 tapi yang memilih hanya 37.875.299 atau 87,86\% (Naru Daruisama, 2014:3)

Dengan tidak adanya partai pemenang mayoritas mutlak dalam Pemilu 1955 maka kabinet yang terbentuk berdasarkan koalisi antara partai-partai pemenang pemilu. Kabinet dimaksud (kabinet pertama hasil pemilu) hanya terdiri dari 3(tiga) partai yakni PNI, Masyumi dan NU, dengan Perdana Menteri dijabat oleh Mr. Ali Sastroamidjojo dari PNI didampingi oleh Mr. M. Roem dari Masyumi sebagi Wakil Perdana Menteri I dan KH. Idham dari NU selaku Wakil Perdana Menteri II. Umur Kabinet ini berlangsung tidak lama hanya lebih kurang1(satu) tahun, oleh kerena adanya perbedaan yang tajam antara PNI yang berideologi nasionalis dan Masyumi berideologi Islam. Selanjutnya Presiden Soekarno selaku Kepala Negara menunjuk seorang tokoh non partai, Ir. Haji Djuanda membentuk kabinet dan menjadi Perdana Menteri; akan tetapi personalia kabinet masih banyak diisi oleh tokoh-tokoh partai seperti dari PNI, NU, PSII dan Partai Kristen (Parkindo), dan juga mulai diisi oleh perwira-perwira militer. Peranan partai pada pembentukan pemerintahan berakhir dengan Dekrit Presiden Soekarno tanggal 5 Juli 1959 yang menyatakan: pembubaran konstituante, kerena kegagalannya merumuskan konstitusi baru, dan memberlakukan kembali Undang-Undang Dasar (UUD) 1945 sebagai Konstitusi Republik Indonesia. Sebagai tindak lanjut dari dekrit itu, Presiden Soekarno membentuk DPR sementara (DPRS), dan lembaga - lembaga negara yang ditetapkan oleh UUD 1945 seperti Majlis Permusyawaratan Rakyat Sementara (MPRS) dan Dewan Pertimbangan Agung Sementara (DPAS). Sistim Demokrasi pun berubah yang dinamakan oleh Presiden Soekarno sebagai "Demokrasi Terpimpin" yang oleh Presiden Soekarno dijabarkan bahwa Demokrasi tanpa terpimpin, itu "anarki", Terpimpin tanpa demorasi itu "diktator". Dalam 
pelaksanaannya semua kebijakan dan kegiatan politik dan pemerintahan ditentukan dan dipimpin oleh Bung Karno.

Faktor-faktor yang mendorong Bung Karno mengeluarkan dekrit adalah (1) kegagalan konstituante menetapkan konstitusi baru yang permanen bagi Indonesia disebabkan perbedaan yang tajam antara kelompok nasionalis yang menginginkan Pancasila sebagai dasar negara versus kelompok Islam yang berkehendak Islam sebagai ideologi dan way of life menjadi dasar negara. Perbedaan itu tidak dapat diselesaikan dengan cara voting disebabkan masing -masing kelompok tidak mencapai dukungan 2/3 dari suara yang hadir sebagaimana diamanatkan oleh konstitusi; (2) ketidakmampuan partai-partai politik mewujudkan pemerintahan yang stabil sebagaimana terlihat pada seringya kabinet bubar disebabkan "mosi tidak percaya dari partai oposisi yang hal ini terjadi dimotivasi pertentangan ideologi dan kepentingan partai, bukan kepentingan nasional; (3) timbulnya pergolakanpergolakan di daerah yang dipimpin oleh panglima-panglima militer setempat dengan menyeret tokoh-tokoh partai tertentu; (4) desakan masyarakat melalui rapatrapat umum agar Presiden Soekarno mengambil tindakan yang revolusionir dengan memberlakukan kembali UUD 1945 sebagai konstitusi negara.

Pada masa Demokrasi Terpimpin, jumlah partai disederhanakan melalui Penetapan Presiden (Penpres) No. 7/1959 dan Penpres berikutnya No 13/1960. Dari kedua Penpres itu diakui 10 (sepuluh) partai politik yakni PNI, NU, PKI, PSII, Parkindo, Partai Katolik, Ikatan Pendukung Kemerdekaan Indonesia-IPKI, Pergerakan Tarbiyah Islamiyah atau Perti, dan Partai Murba serta Partai IndonesiaPartindo. Masyumi dan Partai Sosialis Indonesia-PSI dinyatakan bubar kerena dianggap terlibat pemberontakan di daerah (PRRI dan Permesta).

Selama era Demokrasi Terpimpin tidak ada pemilu dikarenakan Presiden Soekarno menilai negara belum cukup stabil untuk mengadakan pemilu. Dan kehidupan/kegiatan politik di kelompokkan kedalam 3(tiga) aliran atau paham yakni kelompok Nasionalis, Agama (khususnya Islam) dan Komunis yang diberi yargon Nasakom. Representasi ketiga kelompok itu tercermin dalam susunan perwakilan dan pimpinan di lembaga-lembaga negara formal seperti DPRS. MPRS, Badanbadan Semi Otonom seperti Kantor Berita Antara dan Badan-badan Usaha Milik Negara, dan Daerah - BUMN dan BUMD dengan resmi dan diakuinya wakil dari golongan komunis yang direpresentasikan oleh PKI maka partai ini memanfa'atkan secara semaksimal untuk membesarkan partai dan menguasai lembaga-lembaga negara yang tujuan akhirnya menguasai negara dan pemerintahan berdasarkan ideologi komunis/marxis baik secara demokratis (pemilu) maupun non demokratis berupa pemberontakan atau kudeta. Hal terakhir itu telah dilakukan PKI dengan melancarkan pemberontakan/kudeta berupa Gerakan 30 September (1965) yang telah membunuh beberapa jenderal yang pada waktu itu sebagai pimpinan teras Angkatan Darat yang oleh PKI jenderal-jenderal itu dianggap anti PKI, dan sekali gus membubarkan kabinet dan menggantinya dengan sebuah lembaga yang dinamainya "Dewan Revolusi". Pemberontakan PKI itu dapat digagalkan oleh rakyat bersama-sama dengan Tentara Nasional Indonesia-TNI dan kekuatankekuatan politik yang anti komunis. Dalam perkembangan selanjutnya Bung Karno, pada tahun 1967 melalui rapat dan keputusan MPRS dinyatakan tidak lagi menjadi Presiden RI, digantikan oleh Jenderal Soeharto, panglima Kostrad yang berhasil 
memimpin penumpasan gerakan PKI itu, G 30 S/PKI. Masa kepemimpinan Bung Karno dalam kamus politik Indonesia sering disebut Era Orde Lama (Old Order) dan masa kepemimpinan Soeharto disebut Era Orde Baru (New Order) dan berlangsung dari tahun 1967 sampai awal tahun 1998 dengan sistim demokrasinya dinamai "Demokrasi Pancasila".

Politik kepartaian pada masa Orde Baru (Orba) masih tetap mengakui adanya partai-partai politik yang jumlahnya berkurang dari era Orde Lama yaitu dengan dibubarkannya PKI dan Partindo, dalam praktek politiknya sangat dekat dengan PKI. Dengan demikian tinggal 8 (delapan) partai yakni PNI, NU, PSII, Parkindo, Partai Katolik, Perti, IPKI dan Murba. Keinginan dari para simpatisan dan eks anggota Masyumi untuk menghidupkan Masyumi tidak disetujui pemerintahan Soeharto, akan tetapi mengizinkan para simpatisan itu mendirikan partai baru yang diberi nama Partai Muslimin Indonesia disingkat Parmusi pada tahun 1968. Selanjutnya pemerintahahn Orde Baru menetapkan pemilu pertama akan dilaksanakan pada tahun 1971 dan akan diikuti 9 partai politik dan satu organisasi kekaryaan bernama Golkar.

Dalam rangka menghadapi Pemilu 1971, pemerintahan Orde Baru mengkonsolidasikan Sekretariat Bersama Golongan Karya disingkat (Sekber Golkar), sebagai gabungan organisasi-organisasi kekaryaan yang mencakup segmen pemuda, mahasiswa, pekerja, militer dan kaum agama yang telah terbentuk pada masa Demokrasi Terpimpin. Sekber Golkar kemudian menjadi suatu organisasi politik yang ikut Pemilu 1971, bernama Golkar namun dalam "kamus Orba, bukan partai politik" dan dalam perkembangan selanjutnya menjadi mesin politik dan penopang utama pemerintahan Orde Baru. Dengan bantuan dan fasilitas militer berupa jaringan intelijen dan penugasan perwira-perwira militer sebagai pengelola dan pembina cabang-cabang lokal Golkar di daerah-daerah, dan politik "monoloyalitas" yang ditetapkan oleh Menteri Dalam Negeri kepada semua pegawai negeri yakni harus memilih Golkar pada pemilu, maka hasilnya Golkar keluar sebagai pemenang pertama dengan perolehan suara sebanyak 34.348673 suara atau $62,82 \%$, diikuti NU, 18,68\%, PNI,6,93\%, Parmusi, 5,36\% dan PSII, 2,39\% sebagai 5 (lima) besar.

Rezim Orde Baru selanjutnya pada tahun 1973 melakukan penyederhanaan partai dengan menetapkan 9 (Sembilan) partai yang ada hendaknya menjadi 2(dua) partai yakni Partai Persatuan Pembangunan (PPP) sebagai fusi dari NU, Parmusi, PSII dan Perti, Partai Demokrasi Indonesia (PDI) gabungan dari PNI, IPKI, Murba, Parkindo dan Partai Katolik. Pada pemilu-pemilu berikutnya, 1977,, 1982, 1987. 1992 dan 1997, kontestan pemilu hanyalah PPP, PDI dan Golkar. Golkar terus menjadi pemenang utama serta dalam konstelasi politik menjadi partai hegemonik, penopang utama dan mesin mobilisasi dukungan untuk pemerintahan Orde Baru.

Kemenangan Golkar itu, menurut para pengamat politik "sudah diatur begitu rupa oleh penguasa agar rezim Orde Baru terus berkuasa" dan tidak mempunyai oposisi yang berarti dikarenakan kecilnya suara yang diperoleh PPP dan PDI. Sejak Pemilu 1977 peranan kedua partai itu hanyalah sebagai pelengkap, "window dressing" bagi sistim demokrasi yang dianut oleh rezim Orde Baru.

Atas desakan rakyat yang dipelopori oleh mahasiswa dan kaum cendekiawan, pemerintahan Orde Baru berakhir dengan lengsernya Soeharto sebagai 
Presiden pada bulan Mei 1998; dan Indonesia memasuki era baru yang dinamakan "Era Reformasi". Era ini ditandai dengan keterbukaan, penghormatan terhadap Hak - hak Asasi Manusia (HAM), demokratisasi dan kebebasan dalam berbagai aspek seperti kebebasan pers, menyatakan pendapat, berserikat, berkumpul termasuk membentuk partai-partai politik.

Dengan keinginan dan rencana pemerintah "Orde Reformasi" untuk mengadakan pemilu secepatnya, maka bermunculan partai-partai politik (parpol) baru. Menjelang pemilu yang akan diadakan pada bulan Juni 1999, telah terdaftar pada Departemen Kehakiman sebanyak 141 partai lama dan baru,, dan setelah diadakan verifikasi hanya 48 partai politik yang memenuhi syarat untuk ikut pemilu. Hasil dari Pemilu 1999, hanya 5 (lima) partai yang memperoleh lebih dari $3 \%$ suara pemilih, 15 partai memperoleh suara berkisar dari 0,2 - 1,9\% dan mendapar kursi DPR, sisanya 28 partai tidak berhasil mendapatkan satu kursi pun. Adapun kelima partai termaksud adalah PDIP, kelanjutan dari PDI yang terbentuk pada masa Orde Baru, 33,7\% dengan perolehan kursi DPR sebanyak (153), Golkar,22,4\% (120), PPP, 10,7\% (58), PKB, partai baru yang lahir pada awal era reformasi, 12,6\% (51), PAN, juga partai baru yang dibentuk pada awal reformasi, mendapatkan suara $7,1 \%$ dengan raihan kursi DPR 34. Partisipasi rakyat pada Pemilu 1999 sebesar 91,69\% dari pemilih yang terdaftar sebanyak 117.738.682 orang, sebanding dengan partisipasi rakyat Indonesia pada pemilu pertama tahun 1955 (Pamungkas 2012: 183).

Pada pemilu - pemilu selanjutnya di Era Reformasi ini jumlah partai peserta pemilu berfluktuasi yaitu pada Pemilu 2004 sebanyak 24 partai, Pemilu 2009 sebanyak 38 partai. Pada Pemilu 2014 sebanyak 12 partai, dan untuk Pemilu 2019 tercatat 16 partai yang telah dinyatakan sah oleh Komisi Pemilihan Umum (KPU) sebagai peserta pemilu.

Sistim Demokrasi yang terwujud dalam Era Reformasi itu bernuansa Demokrasi Liberal yang ditandai banyak kebebasan seperti kebebasan berserikat dengan mudahnya mendirikan partai dan organisasi kemasyarakatan (ormas), dan mengeluarkan pendapat melalui media cetak dan elektronik yang mana menerbitkan media-media cetak tanpa izin lagi dari pemerintah yang dahulu dikenal dengan Surat Izin Terbit (SIT) dan banyak lagi-lagi kebebasan yang dirasakan oleh masyarakat sepanjang Pemilihan Presiden dan Wakil Presiden untuk pertama kali dalam sejarah Republik Indonesia, mulai tahun 2004 dilaksanakan secara langsung oleh rakyat, tidak lagi melalui lembaga-lembaga perwakilan seperti MPR. begitupun pada tahun berikutnya, 2005, Pemilihan-pemilihan kepala daerah, Gubernur/Wakil Gubernur, Bupati/Wakil Bupati, dan Walikota/Wakil Walikota dilaksanakan secara langsung dan bebas oleh rakyat. Peranan lembaga perwakilan seperti DPR berkembang begitu rupa, tidak lagi hanya semata-mata sebagai pengesah atau "tukang stempel" setiap kebijakan pemerintah seperti pada masa Orde Baru, tetapi sebagai penyeimbang dan pengawas terhadap lembaga eksekutif (pemerintah), dan malahan untuk pengangkatan jabatan-jabatan tertentu seperti Panglima Tentara (TNI) dan Polisi (Polri) harus mendapat persetujuan DPR; begitupun untuk pengangkatan Duta-Duta Besar, yang sebelumnya tidak memerlukan persetujuan atau pertimbangan DPR, sekarang harus mendapat pengesahan DPR melalui prosedur yang dinamai Uji Kelayakan dan Kepatutan atau Fit and Proper Test. 
Negara Indonesia sejak berdiri pada tahun 1945 sampai kini terus menerus menganut sistim politik demokrasi dengan bermacam sebutan atau predikat yang dalam praktek politiknya terdapat berbagai variasi dan penekanan, namun dari segi teori yakni pemikiran tentang demokrasi atau school of thought democracy, praktek demokrasi di Indonesia masih dapat di golongan kedalam sistim politik demokrasi. Menurut Roger Hilsman dalam bukunya The Politics of Governing America (1985) berdasarkan literature yang ada, terdapat 3 (tiga) pemikiran atau Schools of Thought tentang Demokrasi yaitu : The Ideological School or Democracy as Ideology; The Classical School of Democracy; dan The Pragmatic School.

Definisi Demokrasi dalam the Ideological School dimulai dengan pengertian bahwa Negara itu muncul atau dibentuk untuk melayani kepentingan individu bukan sebaliknya. Konsekwensi selanjutnya adalah rakyat berhak untuk memilih orangorang mereka untuk duduk dalam pemerintahan dan ataupun ikutserta dalam pemerintahan. Karakteristik utama dalam Demokrasi sebagai Ideologi adalah kebebasan (freedom, seperti freedom of Speech, of religion, of assembly and of freedom to engage in political activity as well as freedom to criticize the government).

Teori Demokrasi dari the Classical School ditandai dengan adanya kelembagaan berupa: Pemilihan (Elections), Parlemen (Legislative Body), Kabinet (Executive) dan Perdana Menteri (Chief Executive Officer). Didalam pemikiran ini suatu negara dapat disebut negara demokrasi apabila ada pemilihan secara teratur untuk memilih wakil-wakilnya duduk dalam parlemen dan menentukan siapa saja yang patut duduk dalam kabinet. Dalam praktek, parlemen dapat menolak atau menerima setiap kebijakan yang diambil kabinet.

Menurut the Pragmatic School, setelah meninjau teori -teori sebelumnya yang dalam praktek, rakyat umum sebenarnya tidak berkuasa penuh, melainkan hanya sejumlah elit, mendefinisikan demokrasi sebagai pengaturan kelembagaan untuk mencapai keputusan politik yang mana individu-individu memerlukan kekuasaan untuk memutuskan sesuatu dengan cara berjuang secara kompetitif dalam suatu pemilihan.

\section{Genealogi Kepartaian}

Eksistensi, tumbuh dan berkembangnya kepartaian di Indonesia ditentukan dan dipengaruhi oleh banyak faktor yang antara lain bertalian erat dengan pembilahan sosial atau social cleavage yang ada di masyarakat (Ambardi, 2009). Pembilahan sosial itulah menjadi basis pembentukan partai politik dan menjadi zona atau wilayah partai untuk mendapat dukungan dari anggota masyarakat

Pembilahan sosial yang terdapat di masyarakat Indonesia bertransformasi kedalam sistim kepartaian di Indonesia, dengan kata lain kepartaian di Indonesia merepresentasikan pembilahan sosial yang ada di dalam masyarakat. Sebagai zona dukungan partai, pada saat kampanye pemilu, partai-partai di Indonesia memobilisasi isu-isu yang menjadi kepentingan anggota masyarakat bersangkutan dan bertindak seolah-olah wakil yang representatif dan berjuang untuk kepentingan seluruh anggota masyarakat yang bersangkutan.

Feith dan Castle, ahli-ahli ilmu politik dari Amerika Serikat yang sering melakukan penelitian tentang pemilu di Indonesia membagi pembilahan sosial 
kepartaian di Indonesia menjadi 5 (lima) kelompok: (1) Nasionalisme Radikal, (2) Tradisionalisme Jawa, (3) Islam, (4) Sosialisme Demokratis, dan (5) Komunis (Feith and Castle, 1988: liii - lix). Pembagian ini merujuk pada aliran-aliran yang ada di masyarakat (di Jawa) dan pengaruh dari ideologi-ideologi dari dunia Barat. Selanjutnya Feth and Castel melukiskan pembilahahn sosial itu sebagai berikut :

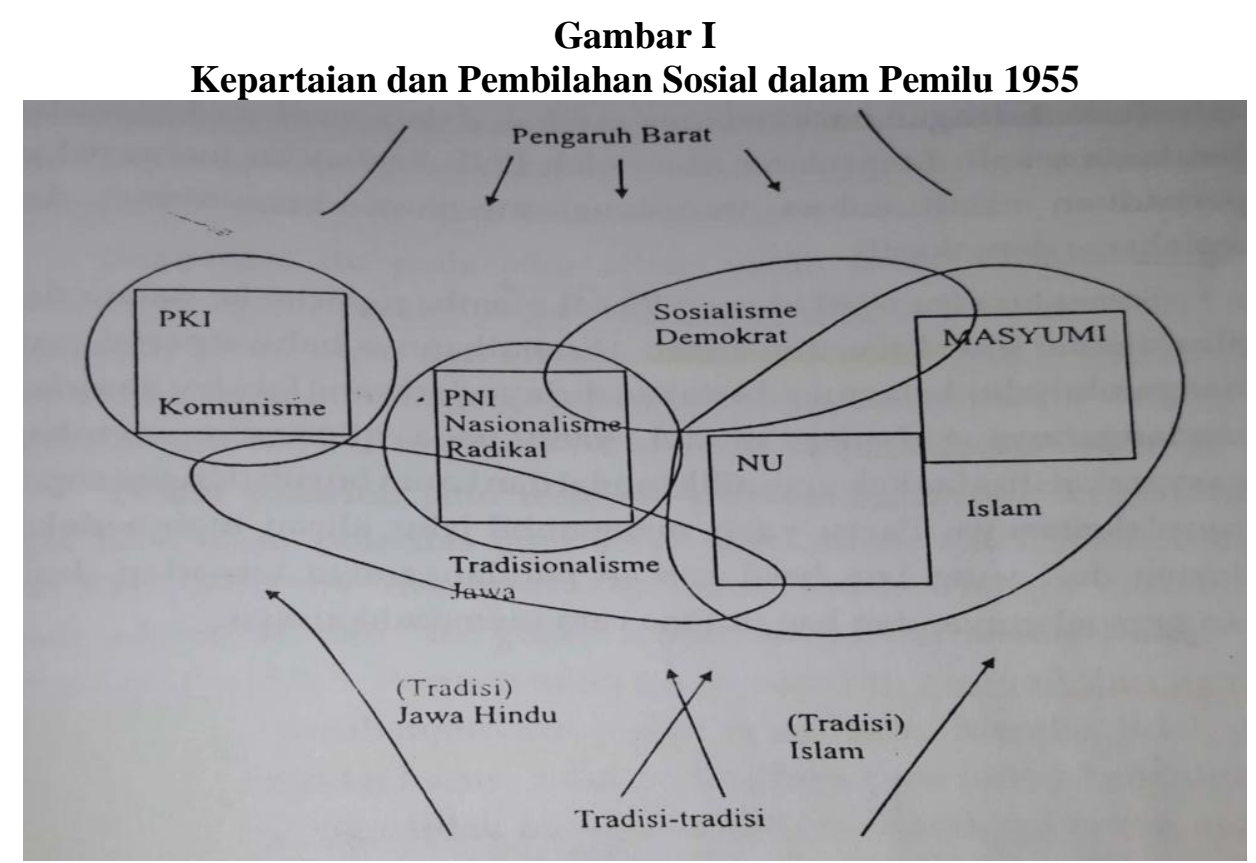

Sumber: Feith dan Castle (1998:iv) dikutip dari Pamungkas (2012: 115)

Menurut pendapat penulis, PNI merupakan representasi dari kaum nasionalis yang kuat, kadang-kadang radikal dan anti pengaruh asing. Secara aliran, kebanyakan menganut paham abangan, percampuran antara Islam tradisional dan pengaruh/warisan hindu budha. Masyumi adalah representasi penganut Islam yang reformis yang mengenyam pendidikan umum, menengah dan tinggi dan dari organisasi-organisasi Islam modern sepereti Muhammadiyah, Al Wasliyah dan Nahdlatul Wathan serta Persis. Nahdlatul Ulama - NU (Partai) sebagai representasi dari penganut Islam tradisional yang teguh memegang paham mazhab (Syafe'i) dan kebanyakan mereka alumni dari pendidikan agama di dalam negeri yakni pesantrenpesantren, dan di luar negeri di Saudi Arabia dan Mesir. Perkumpulan agama yang mereka ikuti adalah NU sebagai ormas. PKI menganut paham komunisme leninisme/marxisme yang dianut oleh kaum abangan terutama di Jawa dan kebanyakan mereka orang-orang miskin yang mengharapkan perubahahn revolusionir untuk menghilangkan kemiskinan yang melilit mereka. Sedangkan paham sosialis demokrat disuarakan oleh Partai Sosialis Indonesia - PSI yang dalam Pemilu 1955 sebagai pemenang ke-7 dengan perolehan suara $753.191(1,99 \%)$ dan raihan 5 kursi DPR Pimpinan dan anggota serta pengikut PSI kebanyakan berpendidikan umum di dalam dan luar negeri yang tertarik dengan ide-ide sosialisme yang berkembang di dunia Barat. 
Adapun aliran dan paham yang mewarnai partai-partai pada Pemilu 1999 diawal Era Reformasi, oleh Daniel Dhakidae dibagi kedalam 2 (dua) jalur yakni jalur Kelas dan Aliran (Dhakidie 1999: 34). Pada jalur Kelas terbagi menjadi dua kelompok yakni berideologi pembangunan (developmentalisme), dan sosialisme radikal. Sementara pada jalur Aliran dipilah menjadi kelompok Agama (Islam dan Kristen) dan kelompok Kebangsaan Selain dari kedua kelompok itu menurut Dhakidae terdapat kelompok tengah yang memadukan jalur kelas dan aliran, merupakan ramuan dari agama, kebangsaan, pembangunan isme dan sosialisme. Paham pembangunan isme dianut oleh partai Golkar, kebangsaan diusung oleh PDIP, kelompok agama Islam direpresentasikan PPP dan PKS dan untuk kelompok Kristen oleh Partai Damai Sejahtera (PDS), untuk kelompok tengah, PAN dan PKB; sedangkan untuk paham sosialisme diwakili Partai Rakyat Demokratik (PRD). Pembilahan kepartaian pada Pemilu 1999 terlihat pada gambar II.

\section{Gambar II}

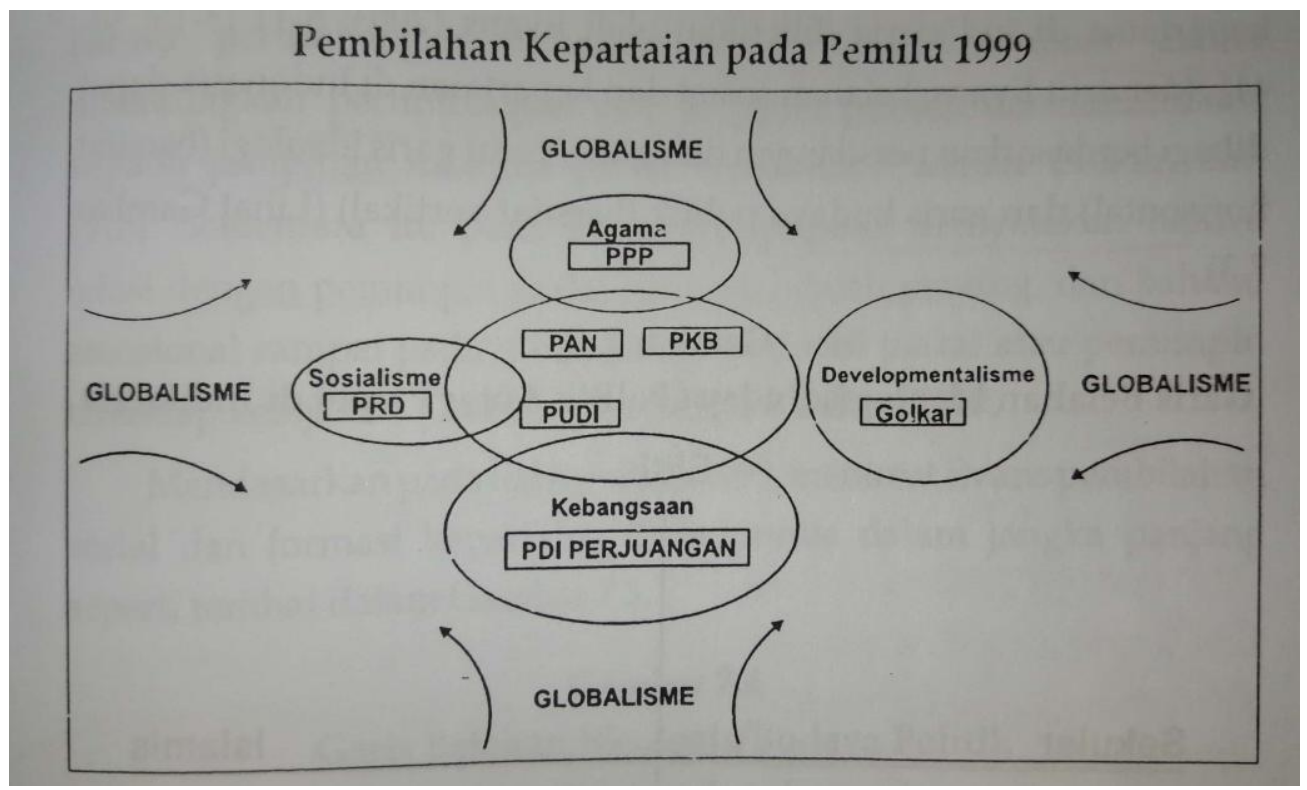

Sumber: Dhakidae (1999:36) dikutip dari Pamungkas (2012: 117)

Pendapat ahli yang lain tentang pembilahan sosial dari kepartaian di Indonesia dikemukakan oleh Evans (2003: 8-15, 30-40). Menurut Evans, belahan sosial dari kepartaiain Indonesia dapat dibagi berdasarkan persilangan dua garis yaitu garis ideologi (bersifat horizontal) dan garis budaya politik (bersifat vertikal), yang kemudian diisi dengan memasukkan 6 (enam) partai pemenang Pemilu 1999 secara berurutan yakni PDIP, Golkar, PPP, PKB, PAN, dan Partai Bulan Bintang PBB. Menurut Evans, spektrum sosial Indonesia terbagi atas kalangan "kiri" atau sekuler dan "kanan" atau agama, dengan pembeda paling dasar bagaimana menempatkan agama dihubungkan atau dihadapkan dengan negara. Kalangan 
sekuler menolah penghususan entitas agama khususnya Islam dalam hubungannya dengan negara. Sementara kalangan agama mendukung transformasi agama ke dalam negara. Dalam sejarah kepartaian di Indonesia, PNI (1955) dan PDIP (1999) merepresentasikan entitas sekuler, sedangkan Masyumi, NU (1955), PPP, PBB (1999) dan partai-partai Islam lainnya merepresentasikan agama (Islam). Pada tataran budaya politik, menurut Evans terpilah menjadi konsentris elites dan populis. Titik konsentris tersebut dibedakan berdasarkan jawaban atas pertanyaan bagaimana politik dikomunikasikan kepada publik. Pada konsentris elitis pertimbangan terhadap posisi kebijakan lebih utama dibandingkan pertimbangan atas loyalitas pribadi dan identifikasi kepada pimpinan nasional partai, contohnya Golkar dan PAN. Pada konsentris populis, relasi dengan pimpinan nasional partai adalah penting dan bahkan bersifat emosional daripada posisi partai dan kebijakan yang diusung; contohnya PDIP dan PKB.

Merujuk pada hasil Pemilu 1999, Evans menggambarkan pembilahan sosial dan formasi kepartaian di Indonesia dalam jangka panjang terlihat dalam gambar (III) berikut ini:

\section{Gambar III}

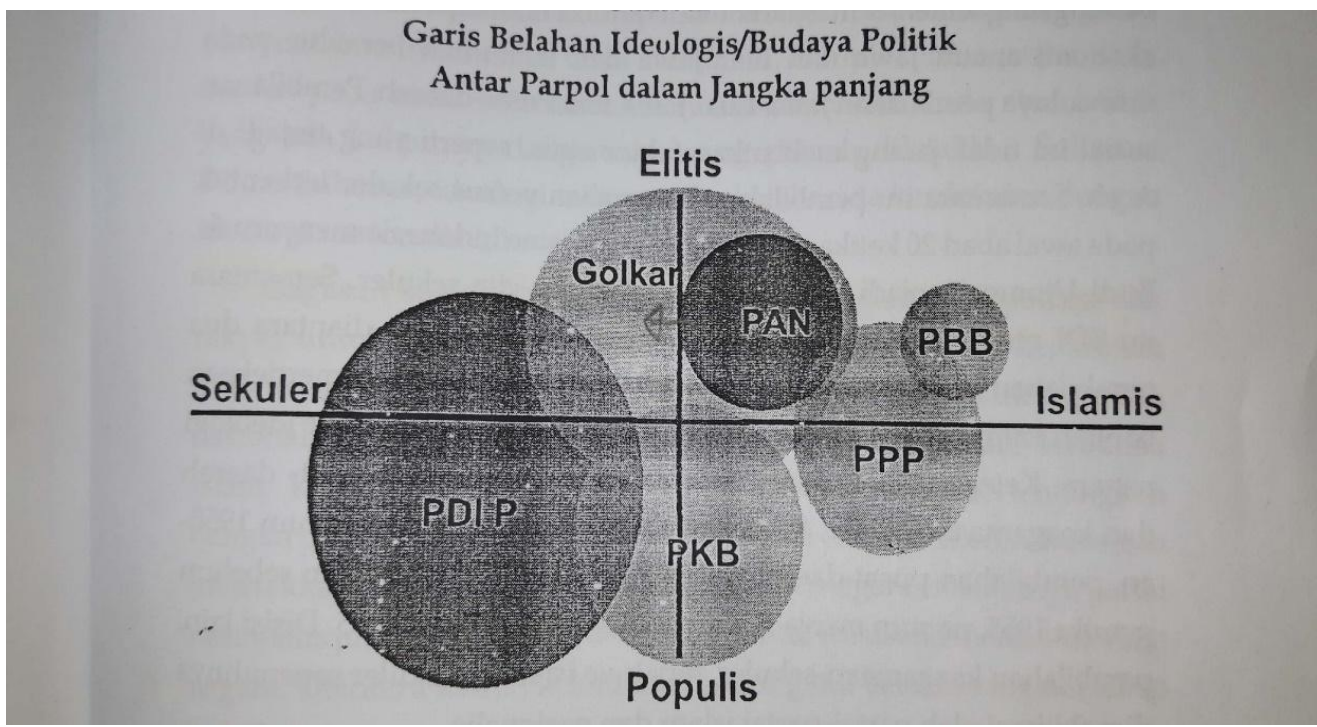

Sumber: Evans (2003:34) dikutip dari Pamungkas (2012: 119)

Menurut pendapat Penulis, pengelompokan partai-partai khususnya peserta Pemilu 1999 dapat dibagi kedalam dua kelompok besar yaitu kelompok Nasionalis Sekuler dan Nasionalis Agamis atau Religius. Dari perspektif ideologi khususnya dengan memakai preferensi ideologi yang berkembang di Eropa dapat dibagi menjadi golongan ekstrem kanan, kanan tengah, ekstrem kiri dan kiri tengah. Untuk kelompok Nasionalis sekuler adalah PDIP, Golkar termasuk partai-partai kecil yang berdasarkan paham kebangsaan seperti PNI Front Marhaenis, Partai Demokrasi Indonesia-PDI; sedangkan kelompok Nasionalis Agamis direpresentasikan oleh PPP, PKS, PAN, PKB, PBB dan partai-partai kecil yang bernuansa Islam seperti Partai Kebangkitan Umat-PKU, Partai Nahdlatul Ummah-PNU, dari golongan 
Kristen seperti PDS. Dari perspektif ideologi (Barat/Eropa), kelompok ekstrem kiri adalah PRD, PDIP, kiri tengah Golkar dan PDI, ektrem kanan, PKS dan PPP. PKU, PNU. Untuk kanan tengah PAN, PKB dan PSII. Pengelompokan secara ideologi ini tidaklah seketat seperti yang terjadi Barat/Eropa, dan posisi partai-partai itu tidaklah permanen tergantung isu-isu yang berkembang di masyarakat dan dibahas di DPR.

Mengenai hubungan agama dengan negara terdapat 3 (tiga) paradigma atau tesis tentang hubungan antar dua entitas itu yakni (1) Integralistik, yang menyatukan agama (Islam) dan negara seperti Republik Islam Iran dan Kerajaan Saudi Arabia. (2) Simbiotik, yakni antara agama dan negara saling membutuhkan, seperti yang dipraktekkan oleh Mesir dan Indonesia, (3) Sekuleristik yang memandang antara agama dan negara saling terpisah dan mempunyai domainnya masing-masing. Paham ini banyak dianut oleh negara-negara di Eropa, dan Amerika Serikat.

\section{Simpulan}

Jumlah partai-partai yang ikut pemilu di Indonesia berfluktuasi tergantung pada sistim politik yang sedang berlaku pada waktu pemilu itu akan dilaksanakan. Pada sistim Demokrasi Liberal (1945 -1950 dan berlanjut sampai 1959) semua orang/perorangan, kelompok masyarakat dan organisasi serta partai politik yang lama dan baru dibolehkan ikut pemilu pada tahun 1955. Tercatat peserta Pemilu 1955 sebanya 100 kontestan. Namun jumlah partai yang ikut Pemilu 1955 hanyalah berjumlah 39. Pada era Demokrasi Terpimpin, jumlah partai yang tercatat pada lembaga pemerintah sebanyak 8, dan pada era ini tidak ada pemilu dikarenakan penguasa pada waktu itu menganggap negara belum cukup stabil untuk menyelenggarakan pemilu yang bebas, langsung dan rahasia. Kerinduan partaipartai untuk ber pemilu, terwujud dengan munculnya pemerintahan Orde Baru atau Orba, yang pada tahun 1971 diadakan lagi pemilu yang dikuti 9 partai lama dan baru, dan organisasi kekaryaan bernama Golkar. Pada Pemilu ini Golkar keluar sebagai pemenang pertama, berhasil mengumpulkan suara sebesar 62,82\%. Peringkat kedua baru diduduki oleh partai yakni NU sebesar 18,68\%. Pada pemilu selanjutnya 1977, 1982, 1987, 1992 dan 1997, kontestan pemilu hanya sebanyak 3 yaitu PPP, gabungan partai-partai agamis (Islam), dan PDI gabungan partai kristen/katolik dan sekuler, serta Golkar yang pada pemilu-pemilu itu selalu keluar sebagai pemenang pertama dan menjadi partai hegemonik.

Pada pemilu-pemilu di Era Reformasi di tahun: 1999, 2004, 2009 dan 2014, partai-partai politik bergairah lagi ikut pemilu, ditandai dengan kemenangan partai, PDIP pada Pemilu 1999, dan Golkar, menjadi Partai Golkar, pada Pemilu 2004. Pada Pemilu 2009, keluar sebagai pemenang adalah Partai Demokrat, partai baru yang lahir pada masa Era Reformasi, dan pada Pemilu 2014 kembali PDIP menjadi pemenang pertama.

Sistim politik sejak negara Indonesia diproklamirkan tetap memakai label Demokrasi dengan berbagai corak dan nuansa dalam pelaksanaannya namun tetap mengandung unsur utama demokrasi yakni adanya partai politik, pemilu dan kebebasan utama yang dimiliki rakyat yakni kebebasan berserikat, berkumpul, dan menyatakan pendapat yang gradasinya bergelombang. 


\section{Daftar Pustaka}

Ambardi, Kuskridho, Mengungkap Politik Kartel, studi tentang Kepartaian di Indonesia Era Reformasi, Jakarta: Gramedia, 2008.

Dhakidee, Daniel, eds, Partai-Partai Politik Indonesia, Ifeologi dan Program, 20042009, Jakarta: PT Kompas, 2011.

Feith, Herbert, Pemilu 1955 di Indonesia, Jakarta: Gramedia, 1999.

Evans, Kevin Raymond, Sejarah Pemilu dan Partai Politik di Indonesia, Jakarta: PT Arise Consultance, 2003.

Naru Darusima, Sejarah Revolusi Kemerdekaan, Pemilihan Umum 1955, Jakarta: Jurnal Sejarah Net, November 2004.

Pamungkas, Sigit, Partai Politik, Teori dan Praktek di Indonesia, Yogyakarta: Institute for Democracy and Welfarism (IDW), 2012

Ridho Al Hamdi, Partai Politik Islam, Teori dan Praktek di Indonesia, Yogyakarta: Graha Ilmu, 2013.

Hilsman, Roger, the Politics of Governing America, New Jersey: Prentice-Hall. 1985 , page $446-453$. 